\title{
Similes In Novel Looking For Alaska By John Green
}

\author{
Ni Putu Antary Octha Sri Devi ${ }^{1 *}$, I Gede Budiasa ${ }^{2}$, A. A. Sagung Shanti Sari Dewi ${ }^{3}$ \\ English Department - Faculty of Arts - Udayana University \\ ${ }^{1}$ [antaryoctha95@gmail.com] ${ }^{2}$ [budiasa.igede@yahoo.com] \\ ${ }^{3}$ [jungshanti@yahoo.com] \\ *Corresponding Author
}

\begin{abstract}
The paper entitled "Similes in Novel Looking for Alaska by John Green" focuses on the kinds of simile and the meaning of simile found in the novel. The data was collected by reading the novel intensively, giving underline and taking note the similes found in the novel. The collected data was analyzed using qualitative method based on theory of figurative language, particularly simile. The main theory used in the analysis of the kinds of simile is proposed by Zhang Xiu Guo in a book entitled English Rhetoric (2005) and the analysis of type of meanings uses theory proposed by Leech (1981) in his book entitled Semantics. From the analysis of the data, there were two types of similes found, namely simile in terms of function and structure. Functionally there were three kinds of simile found, they are descriptive, illuminative, and illustrative similes, meanwhile structurally two kinds of similes were identified, they are closed and open similes. The meanings of similes found are connotative and conceptual meanings.
\end{abstract}

Keyword: Simile, Types, Meaning

\begin{abstract}
Abstrak
Judul dari penelitian ini adalah Similes pada novel “ Looking For Alaska By John Green" berfokus pada jenis simile, dan makna simile yang ditemukan dalam novel ini. Pengumpulan data dengan membaca novel secara intensif, memberikan garis bawah dan mencatat similes yang ditemukan dalam novel tersebut. Data yang terkumpul dianalisis dengan menggunakan metode kualitatif berdasarkan teori bahasa kiasan, terutama simile. Teori utama yang digunakan dalam analisis jenis simile diusulkan oleh Zhang Хіи Guo dalam sebuah buku berjudul English Rhetoric (2005: 158-159) dan jenis analisis makna menggunakan teori yang diajukan oleh Leech (1981) dalam bukunya yang berjudul Simantic. Dari analisis data, simile dapat dikelompokkan menjadi dua jenis: simile dalam hal fungsi dan struktur. Secara fungsional simile dapat diklasifikasikan dalam tiga jenis: deskriptif, iluminatif, dan ilustratif. Dari segi struktur simile bisa dibagi dalam dua jenis, simile tertutup dan terbuka. Makna dari simile yang ditemukan adalah makna konotatif dan konseptual.
\end{abstract}

Kata kunci: Similie, Tipe, Arti

\section{Background of the Study}

Figurative language or figure of speech is a word or phrase used in a different way from its usual meaning in order to create a particular mental picture effect (Hornby, 2005:527). Meaning is the thing or idea that people wishes to communicate to you by what they say or 
do (Oxford Advance Learner's Dictionary, 2005:951). Larson (1997) states that there are many kinds of figurative language such as: metonymy, synecdoche, idiom, euphemism, hyperbole, metaphors, and simile.

One of the figurative languages like simile presents two comparisons in the semantic structure. It is referring to how to use the word "like" or "as" to make the comparison within one thing to another, and also to compare one object with another to suggest they are alike. A simile is a figure of speech that directly compares two things and is always stated clearly through comparison by using of the word "like" or "as". For example, "she is beautiful like a sun flower. This sentence of simile can image that the girl is compared as a sun flower. "She is beautiful like a sun flower" can mean that the girl is a pretty person. It also means that every beautiful person can be compared to a sun flower. It is because the sun flower is the symbol of beauty. It is very interesting to find the features or characteristic of something. Simile and figurative simile are used in various ways, such as in literature or media. Simile is usually used in poem, song lyrics, advertisement, short stories, novels, etc. Novel is a kind of media that is used to express feeling. Novel is a story long enough to fill a complete book, in which the characters and events are usually imaginary (Hornby, 2005:1039). A novel was chosen as the data of this study in order to get a lot of similes. The novel "Looking for Alaska" written by John Green is selected as the data source of this study rather than other author because he is one of the authors who has bestselling novel and also almost in all of his novels contain a lot of examples of simile. It is interesting to identify the similes that are used in this novel in order to imagine about the feelings of the author and sentences in this novel are easy to understand by the readers. Therefore, it is very interesting to analyze the similes found in the novel.

\section{Problem of the study}

In this study, there are two problems formulated to analyse the similes used in the novel "Looking for Alaska" :

1. What types of similes are found in the novel "Looking for Alaska" in terms of function and structure?

2. How is the simile implied in terms of meaning in the novel "Looking for Alaska"?

\section{Aims of the Study}

The aims of the current study are as follows:

1. To identify the kinds of simile found in the novel "Looking For Alaska" in terms of function and structure

2. To analyze the types of meaning of simile in the novel "Looking For Alaska".

\section{Research Method}

The research method in this study consists of data source, method and technique of collecting data, method and technique of analyzing the data, and method and technique of presenting data.

\subsection{Data source}

The primary data in this study were taken from a novel. The data of this study was collected from a novel written by John Green entitled Looking for Alaska. This novel contains many similes. Looking for Alaska was eventually completed and published in 2005. It is a coming-of-age romance novel about a teen Miles. The novel is inspired by Green's time at Indian Springs. Unlike other young adult writers, Green has broadened the horizon of young adult novels subjects matter. 
This novel explains philosophical approach to the issues of teenager's life. The unorthodox form and content of the novel had it earned the American Library Association's Michael L. Printz Award in 2006. The book made a record for staying at New York Times as best seller as list for the span of 7 years. Looking for Alaska consists of 268 pages with 59 chapters. The novel follows Miles Halter, a new junior at the school who is navigating the adolescent world of making friends, pranking the wealthy day students, finding romance, and searching for The Great Perhaps. There are many similes in this novel and make this story interesting for the readers.

\subsection{Method and Technique of Collecting Data}

The method of collecting data was documentation. The techniques in collecting data are; first, reading the data carefully and rereading in order to get understanding of this novel; second, giving underline and taking a note of all similes found in the novel page by page; third taking all of similes in the novel; and the fourth, analyzing the data that have been classified

\subsection{Method and Technique of Analyzing Data}

The collected data were analyzed by using the descriptive method proposed by Guo and use the theory of meaning proposed by Leech. In this study, there were several steps taken in analyzing the data. First, reading and understanding the object of the study; it was very important to read the whole novel carefully, and try to understand the message or the main point of the novel. After that, the data analysis started by classifying the data into the type of simile. Underlining the sentences and taking a note in order to identify simile words. Classifying kinds of simile in term of function, and in term of structure. Next, the meaning of the simile in the novel was described, identified, and analyzed based on the theory. By analyzing the simile, what the novel means by the author could be interpreted.

\section{Analysis}

5.1 Kinds of simile in the novel Looking for Alaska

1. In terms of Function

a. Descriptive similes

Alaska made $\mathrm{O}$ with her lips, moving her mouth like a goldfish eating (chapter 6:55). This simile refers to descriptive simile because the condition of her lips explains the goldfish eating of the tight which can be seen from the word $\mathrm{O}$.

\section{b. Illuminative Similes}

My head still hurt, and sizeable knot above my left temple looked, the colonel though, like a miniaturized topographical map Macedonia.(Green, 2011:83).

This simile belongs to illuminative simile because the characteristics of miniaturized topographical map Macedonia being the sizeable knot so that simile gives deeper insight into how the sizeable knot of Miles' head.

\section{c. Illustrative similes}

Alaska followed the smoke rings with her fingers, stabbing at them like a kid trying to pop bubbles (Green, 2011:70).

This simile belongs to illustrative simile because it illustrates how Alaska pops the bubble.

\section{In terms of Structure}

a. Open Simile

We ran like we had golden shoes (Green, 2011:128). 
This simile refers to open simile because the qualities or characteristics of golden shoes unstated.

\section{b. Closed Simile}

A cylindrical orange object getting bigger and bigger, like a fast approaching sun (Green, 2011:76).

This simile occurs as closed simile because the characteristic of a sun is clearly stated, as being orange object, basket ball.

\subsection{Meaning of Simile in the novel Looking for Alaska}

\section{A. Conceptual Meaning}

Alaska made $\mathrm{O}$ with her lips, moving her mouth like a goldfish eating (Green, 2011:55).

The sentence above contains a conceptual meaning as all of the meanings in the sentence are already described in the sentence. The concept of a goldfish is explained that it can live in any kind of water and got round shape for its mouth. The sentence represents how Alaska looks like a gold fish eating in the water. Fish that is eating something will make a circle in mouth. The sentence explains that Alaska makes $\mathrm{O}$ with her lips, as condition shape of mouth Alaska is clearly stated as eating fish.

\section{B. Connotative Meaning}

1. Grabbed it with both hands and collapsed into chair with a series of quick, shallow breath like a woman in labour (Green, 2011:86).

This sentence has connotative meaning as it cannot be interpreted literally. The phrase "like woman in labour" gives deeper meaning of the condition of a woman who is giving birth with a heavy breath. The author of this novel explains that Hyde is very old lecturer, and this condition cannot be supposed to be allowed to walk so far away but he has to walk into the classroom, and makes him feel very exhausted because he walks too far. It is a connotative meaning because meaning of this sentence cannot be understood literally; everyone will translate it differently depending on their knowledge or experience.

\section{Conclusion}

Based on the foregoing analysis and discussion, the following points can be drawn as conclusion:

Functionally the similes are descriptive, illuminative and illustrative simile. Descriptive similes use vivid and effective description; they can draw sharp pictures in the mind with brevity. Illuminative similes give deeper insight into persons, things, ideas, even problems through suggestive association. They are used to throw light into what would otherwise to be inconceivable to ordinary people; and Illustrative similes explain abstract or complicated ideas of processes in simple, concrete imagery. They are often used in scientific, technological writing. Structurally they are open and close simile. Open similes refers to the simile with which the common quality of the two unlike elements is unstated. It is left for the readers or listeners to comprehend; and closed similes refer to the simile with which the common quality or the ground of the comparison is clearly stated.

Meanwhile as far as the meanings of simile are concerned, they are conceptual and connotative meanings. Conceptual meaning is the clear and logical definition of a word based on the structure and form of the word. Connotative meaning is the communicative value that an expression has by virtue of what it refers to, over and above its purely conceptual content. 


\section{Bibliography}

Chomsky, Noam (1957). Syntactic Structure. Martino Fine Book, USA.

Hornby, Albert Sidney. (2010). Oxford Advanced Learner's Dictionary. Eighth Edition. Oxford University Press, Oxford.

Larson, Mildred L. 1997. Meaning-Based Translation. University Press of America. Maryland.

Leech, Geoffrey. (1979). Semantics. Penguin Books. Auckland.

Xiu Guo, Zhang. (2005). English rhetoric. "Qing Hua Xue Chu Ban She". Tsinghua University Press. Beijing 